\title{
EFFECT OF INOSINE ON RED CELL PRESERVATION ${ }^{1}$
}

\author{
By ROBERT D. LANGE,² WILLIAM H. CROSBY, DENNIS M. DONOHUE, CLEMENT \\ A. FINCH, JOHN G. GIBSON, II, THOMAS J. McMANUS, AND \\ MAX M. STRUMIA \\ (From the Department of Hematology, Walter Reed Army Institute of Research; Department \\ of Medicine, University of Washington School of Medicine; Department of \\ Medicine, Harvard Medical School; and Laboratory of Clinical \\ Pathology, Bryn Mawr Hospital, Bryn Mawr, Pa.)
}

(Submitted for publication April 3, 1958; accepted July 17, 1958)

The addition of inosine, a purine nucleoside, to acid-citrate-dextrose (ACD) solution has been proposed as a means for prolonging the storage period of blood used for transfusion purposes (1). Inosine appears to affect the carbohydrate and phosphate metabolism of the erythrocyte and thereby improve the viability of stored red cells (1).

Since an increase in the outdating period of blood would be of great value, this study was undertaken by four different laboratories in order to compare standard acid-citrate-dextrose and acid-citrate-dextrose-inosine (ACDI) as blood preservatives. In 109 studies the comparison of ACD and ACDI was made by biochemical and hematologic tests done in vitro and the survival of transfused $\mathrm{Cr}^{51}$-tagged red cells measured in vivo.

This report is a compilation of the results obtained in all four laboratories.

\section{METHODS}

For each study approximately $450 \mathrm{ml}$. of blood was collected from healthy human volunteers in either ACD or ACDI solution. If less than $450 \mathrm{ml}$. of blood was collected this is indicated in the tables and figures. Both preservative solutions contained $67.5 \mathrm{ml}$. ACD, NIH Formula A. For the ACDI solution, $1.8 \mathrm{Gm}$. of inosine ${ }^{3}$ was added to the ACD solution before autoclaving. In 15 studies two different inosine preparations ${ }^{4}$ were tested and Seitz filtration was used as the method of sterilization. Three types of containers were purchased. Glass bottles were supplied by Baxter Laboratories. Type F plastic packs with attached donor set were supplied by the

\footnotetext{
1 This project was sponsored by the National Research Council.

2 Present address: Washington University School of Medicine, St. Louis, Mo.

3 Purchased from Schwartz Laboratories.

4 One preparation obtained from Zellstoff WaldhofWerke, Mannheim, Germany; one preparation obtained from Schwartz Laboratories.
}

Fenwall Laboratories. Type $\mathrm{C}$ plastic packs without an attached donor set were supplied by the Cutter Laboratories.

Following collection, the blood was stored at $4^{\circ} \mathrm{C}$. for periods of 20 to 43 days. After various time intervals of in vitro storage, portions of the blood were tagged with $\mathrm{Cr}^{\text {s1 }}$ and transfused to the original donor or to appropriate recipients. The methods of $\mathrm{Cr}^{51}$ tagging have been previously described (2-5). From 30 to $87.3 \mu \mathrm{c}$. of $\mathrm{Cr}^{\text {s1 }}$ was used with specific activities of from 0.90 to $1.752 \mathrm{mc}$. per mg. The survival rate was determined. The method for estimating the recipient's red cell volume differed in each laboratory. Dr. Strumia's group estimated the blood volume by the Evans blue dye method (2). Dr. Gibson's and Dr. Finch's groups used $\mathrm{P}^{32}$ by methods already published by each independently $(3,4)$. Dr. Crosby's group used radioiodinated serum albumin (RISA (5)) (5). The method for estimating the red cell volume did not appear to affect the results and for the purpose of presentation the survival results from each group were averaged. The apparent half-time survival of the red cells $(T / 2)$ was calculated where possible.

In four studies, after 21 or 28 day storage periods, a sample was removed for tests in vivo and in vitro and the blood was immediately returned to the refrigerator. Following a further two week storage period, the same tests were repeated on the same blood and in the same subject. For these studies, one-half of the usual amount of $\mathrm{Cr}^{51}$ was used for each in vivo study.

In four studies an entire unit of whole blood was transfused. The $\mathrm{Cr}^{51}$ was added directly to the entire unit of blood. During the transfusion the pulse and blood pressure were measured every five minutes. The uric acid content of 24 hour urine samples was measured in two instances.

In 39 of the studies, in vitro tests were performed on the day of collection and again on the day of transfusion. These included determinations of: 1) mean corpuscular hemoglobin concentration ( $\mathrm{MCHC}), 2$ ) plasma $\mathrm{Na}, 3$ ) plasma $\mathrm{K}$, and 4) plasma hemoglobin. No attempt was made to correct the plasma $\mathrm{K}$ for the potassium contributed by the lysed erythrocytes. In 41 studies the following in vitro determinations were made on the day of transfusion: 1) mean corpuscular volume, 2) $\mathrm{pH}, 3$ ) lactic acid, 4) dextrose, 5) adenosine triphosphate, and 6) percentage of hemolysis in 0.63 and 0.60 per cent $\mathrm{NaCl}$. 
TABLE I

Comparison of $A C D$-inosine and $A C D$ as blood preservatives

\begin{tabular}{|c|c|c|c|c|c|c|c|}
\hline Subject & $\begin{array}{c}\text { Days } \\
\text { storage }\end{array}$ & MCHC & $\mathrm{Na}$ & $\mathbf{K}$ & $\begin{array}{l}\text { Plasma } \\
\text { hb. }\end{array}$ & $\begin{array}{l}24 \mathrm{hr} \text {. } \\
\text { survival }\end{array}$ & $\mathrm{T} / 2$ \\
\hline & & $\%$ & $\begin{array}{l}m E q . / L . \\
\text { Group I. }\end{array}$ & $\begin{array}{c}m E_{q .} / L \\
\text { ACDI in bottles }\end{array}$ & mg. $\%$ & $\%$ & days \\
\hline 1 & $\begin{array}{r}0 \\
21\end{array}$ & $\begin{array}{l}33.5 \\
32.0\end{array}$ & $\begin{array}{l}170.5 \\
148.7\end{array}$ & $\begin{array}{r}3.9 \\
33.3\end{array}$ & $\begin{array}{l}33.6 \\
65.0\end{array}$ & 95 & 24 \\
\hline 2 & $\begin{array}{r}0 \\
21\end{array}$ & $\begin{array}{l}31.4 \\
32.2\end{array}$ & $\begin{array}{l}164.1 \\
153.2\end{array}$ & $\begin{array}{r}4.0 \\
25.0\end{array}$ & $\begin{array}{r}3.8 \\
60.5\end{array}$ & 92 & 31 \\
\hline 3 & $\begin{array}{r}0 \\
28\end{array}$ & $\begin{array}{l}32.0 \\
32.5\end{array}$ & $\begin{array}{l}172.0 \\
143.0\end{array}$ & $\begin{array}{r}4.1 \\
31.8\end{array}$ & $\begin{array}{r}20.5 \\
140.0\end{array}$ & 71 & 28 \\
\hline 4 & $\begin{array}{r}0 \\
28\end{array}$ & $\begin{array}{l}31.6 \\
32.2\end{array}$ & $\begin{array}{l}172.0 \\
140.0\end{array}$ & $\begin{array}{r}3.8 \\
30.9\end{array}$ & $\begin{array}{r}11.0 \\
110.0\end{array}$ & 75 & 27 \\
\hline 5 & $\begin{array}{r}0 \\
35\end{array}$ & $\begin{array}{l}31.5 \\
33.0\end{array}$ & $\begin{array}{l}174.2 \\
137.5\end{array}$ & $\begin{array}{r}4.4 \\
33.8\end{array}$ & $\begin{array}{l}16.2 \\
90.0\end{array}$ & 65 & 20 \\
\hline 6 & $\begin{array}{r}0 \\
35\end{array}$ & $\begin{array}{l}31.5 \\
32.4\end{array}$ & $\begin{array}{l}174.2 \\
142.5\end{array}$ & $\begin{array}{r}4.1 \\
36.3\end{array}$ & $\begin{array}{r}13.0 \\
165.0\end{array}$ & 99 & 26 \\
\hline $7^{*}$ & 36 & & & & & 63 & \\
\hline $8^{*}$ & 36 & & & & & 77 & \\
\hline $9 *$ & 36 & & & & & 53 & \\
\hline $10 \dagger$ & 39 & & & & & 20 & \\
\hline $11 \dagger$ & 39 & & & & & 30 & \\
\hline $12^{*}$ & 42 & & & & & 50 & \\
\hline $13^{*}$ & 42 & & & & & 69 & \\
\hline $14^{*}$ & 42 & & & & & 59 & \\
\hline $15^{*}$ & $\begin{array}{r}0 \\
42\end{array}$ & $\begin{array}{l}30.0 \\
30.7\end{array}$ & $\begin{array}{l}167.5 \\
149.0\end{array}$ & $\begin{array}{r}4.7 \\
36.9\end{array}$ & $\begin{array}{r}16.2 \\
216.0\end{array}$ & 72 & 23 \\
\hline 16 & $\begin{array}{r}0 \\
42\end{array}$ & $\begin{array}{l}30.2 \\
30.0\end{array}$ & $\begin{array}{l}157.5 \\
140.0\end{array}$ & $\begin{array}{r}4.0 \\
34.4\end{array}$ & $\begin{array}{r}10.0 \\
205.0\end{array}$ & 32 & 20 \\
\hline 17 & $\begin{array}{r}0 \\
21\end{array}$ & $\begin{array}{l}30.7 \\
29.0\end{array}$ & $\begin{array}{c}\text { Group II. } \\
152.5 \\
152.0\end{array}$ & $\begin{array}{c}\text { ACD in bottles } \\
4.4 \\
23.0\end{array}$ & $\begin{array}{r}26.0 \\
120.0\end{array}$ & 69 & 25 \\
\hline 18 & $\begin{array}{r}0 \\
21\end{array}$ & $\begin{array}{l}30.8 \\
31.5\end{array}$ & $\begin{array}{l}160.0 \\
159.0\end{array}$ & $\begin{array}{r}4.5 \\
21.0\end{array}$ & $\begin{array}{r}15.3 \\
145.0\end{array}$ & 73 & 30 \\
\hline 19 & $\begin{array}{r}0 \\
28\end{array}$ & $\begin{array}{l}29.8 \\
30.8\end{array}$ & $\begin{array}{l}161.2 \\
147.5\end{array}$ & $\begin{array}{r}4.1 \\
34.8\end{array}$ & $\begin{array}{r}29.0 \\
205.0\end{array}$ & 69 & 34 \\
\hline 20 & $\begin{array}{r}0 \\
28\end{array}$ & $\begin{array}{l}30.9 \\
30.4\end{array}$ & $\begin{array}{l}167.5 \\
156.2\end{array}$ & $\begin{array}{r}4.6 \\
26.0\end{array}$ & $\begin{array}{l}14.0 \\
85.0\end{array}$ & 76 & 25 \\
\hline 21 & $\begin{array}{r}0 \\
21\end{array}$ & $\begin{array}{l}30.0 \\
30.3\end{array}$ & $\begin{array}{c}\text { Group III. } \\
145.0 \\
154.5\end{array}$ & $\begin{array}{c}\text { ACD in F bags } \\
4.1 \\
29.6\end{array}$ & $\begin{array}{r}4.3 \\
92.0\end{array}$ & 90 & 20 \\
\hline 22 & $\begin{array}{r}0 \\
21\end{array}$ & $\begin{array}{l}30.8 \\
31.3\end{array}$ & $\begin{array}{l}165.1 \\
159.5\end{array}$ & $\begin{array}{r}4.5 \\
23.3\end{array}$ & $\begin{array}{r}2.8 \\
22.0\end{array}$ & 78 & 30 \\
\hline 23 & $\begin{array}{r}0 \\
28\end{array}$ & $\begin{array}{l}30.3 \\
28.4\end{array}$ & $\begin{array}{l}170.0 \\
137.5\end{array}$ & $\begin{array}{r}4.0 \\
31.3\end{array}$ & $\begin{array}{r}2.8 \\
214.0\end{array}$ & 54 & 23 \\
\hline 24 & $\begin{array}{r}0 \\
28\end{array}$ & $\begin{array}{l}28.9 \\
30.3\end{array}$ & $\begin{array}{l}147.1 \\
140.0\end{array}$ & $\begin{array}{r}4.3 \\
30.8\end{array}$ & $\begin{array}{r}2.5 \\
194.0\end{array}$ & 80 & 28 \\
\hline
\end{tabular}

* Four hundred twenty-five ml. blood collected.

$\uparrow$ Two hundred ml. blood collected. 
TABLE II

Comparison of $A C D$-inosine and $A C D$ as blood preservatives

\begin{tabular}{|c|c|c|c|c|c|c|c|c|c|c|c|c|c|}
\hline Subject & $\begin{array}{c}\text { Days } \\
\text { storage }\end{array}$ & MCV & MCHC & $\mathrm{pH}$ & $\begin{array}{l}\text { Lactic } \\
\text { acid }\end{array}$ & Dextrose & ATP & $\mathrm{Na}$ & $\mathbf{K}$ & $\begin{array}{c}\text { Plasma } \\
\text { hb. }\end{array}$ & $\begin{array}{c}\text { Hemolysis } \\
0.63 \% \\
\mathrm{NaCl}\end{array}$ & $\begin{array}{l}\text { 24-hr. } \\
\text { survival }\end{array}$ & $T / 2$ \\
\hline & & $c u . \mu$ & $\%$ & & ms. \% & $\begin{array}{l}\text { mg. \% } \\
\text { up IV. }\end{array}$ & $\begin{array}{c}\text { mg. \% } \\
\mathrm{ACDI} \text { in }\end{array}$ & $\begin{array}{l}m E q . / L \\
\mathrm{~F} \text { bags }\end{array}$ & $m E q_{.} / L$ & mg. \% & $\%$ & $\%$ & days \\
\hline 25 & $\begin{array}{r}0 \\
21\end{array}$ & & $\begin{array}{l}32.1 \\
30.9\end{array}$ & & & & & $\begin{array}{l}161.2 \\
143.0\end{array}$ & $\begin{array}{r}3.9 \\
31.5\end{array}$ & $\begin{array}{l}13.0 \\
61.5\end{array}$ & & 92 & 36 \\
\hline 26 & $\begin{array}{r}0 \\
21\end{array}$ & & $\begin{array}{l}30.6 \\
32.6\end{array}$ & & & & & $\begin{array}{l}160.0 \\
132.0\end{array}$ & $\begin{array}{r}4.2 \\
33.0\end{array}$ & $\begin{array}{r}6.4 \\
21.9\end{array}$ & & 97 & 30 \\
\hline 27 & 21 & 86 & & 6.70 & 134 & 311 & 9.38 & & & 12.0 & 4 & 87 & 24 \\
\hline 28 & 21 & 89 & & 6.75 & 162 & 389 & 8.94 & & & 14.0 & 3 & 82 & 31 \\
\hline 29 & 28 & 89 & & 6.53 & 166 & 314 & 9.27 & & & 42.0 & 14 & 76 & 21 \\
\hline 30 & 28 & 89 & & 6.67 & 214 & 333 & 7.44 & & & 19.0 & 5 & 76 & 25 \\
\hline 31 & $\begin{array}{r}0 \\
28\end{array}$ & & $\begin{array}{l}31.0 \\
33.2\end{array}$ & & & & & $\begin{array}{l}165.0 \\
125.2\end{array}$ & $\begin{array}{r}3.9 \\
43.8\end{array}$ & $\begin{array}{l}14.5 \\
37.0\end{array}$ & & 83 & 25 \\
\hline $32 *$ & $\begin{array}{r}0 \\
28 \\
0 \\
28\end{array}$ & & $\begin{array}{l}31.6 \\
32.2 \\
31.0 \\
28.1\end{array}$ & & & & & $\begin{array}{l}168.7 \\
139.5 \\
161.0 \\
150.0\end{array}$ & $\begin{array}{r}4.2 \\
34.8 \\
4.6 \\
16.3\end{array}$ & $\begin{array}{r}6.6 \\
20.0 \\
4.5 \\
20.0\end{array}$ & & 81 & 29 \\
\hline 33 & 34 & 89 & & 6.63 & 180 & 340 & 8.94 & & & & 9 & 55 & 22 \\
\hline 34 & 34 & 92 & & 6.60 & 248 & 282 & 8.15 & & & 58.0 & 7 & 34 & 20 \\
\hline 35 & 35 & & 32.9 & 6.57 & & & 3.04 & & & 39.0 & $11 \dagger$ & 57 & \\
\hline 36 & 35 & & 34.1 & 6.51 & & & 3.57 & & & 42.0 & $14 \dagger$ & 63 & \\
\hline 37 & $\begin{array}{r}0 \\
35\end{array}$ & & $\begin{array}{l}31.1 \\
32.2\end{array}$ & & & & & $\begin{array}{l}170.7 \\
139.0\end{array}$ & $\begin{array}{r}5.6 \\
20.6\end{array}$ & $\begin{array}{r}8.4 \\
16.5\end{array}$ & & 68 & 29 \\
\hline 38 & $\begin{array}{r}0 \\
35\end{array}$ & & $\begin{array}{l}32.3 \\
31.7\end{array}$ & & & & & $\begin{array}{l}160.0 \\
138.0\end{array}$ & $\begin{array}{r}4.6 \\
32.5\end{array}$ & $\begin{array}{r}5.9 \\
27.0\end{array}$ & & 76 & 27 \\
\hline 39 & $\begin{array}{r}0 \\
42\end{array}$ & & $\begin{array}{l}31.3 \\
32.7\end{array}$ & & & & & $\begin{array}{l}165.0 \\
142.5\end{array}$ & $\begin{array}{r}4.6 \\
35.8\end{array}$ & $\begin{array}{r}5.4 \\
107.5\end{array}$ & & 73 & 25 \\
\hline 40 & $\begin{array}{r}0 \\
42\end{array}$ & & $\begin{array}{l}32.0 \\
32.9\end{array}$ & & & & & $\begin{array}{l}174.2 \\
142.5\end{array}$ & $\begin{array}{r}5.2 \\
35.8\end{array}$ & $\begin{array}{r}5.4 \\
146.0\end{array}$ & & 37 & 24 \\
\hline 41 & 42 & & 33.3 & 6.49 & & & & & & 50.0 & $21 \dagger$ & 48 & \\
\hline 42 & 43 & & 30.3 & 6.54 & & & 3.62 & & & 115.0 & $33 \dagger$ & 65 & \\
\hline 43 & 43 & 85 & & 6.54 & 275 & 279 & 2.49 & & & & 15 & 35 & 14 \\
\hline 44 & 43 & 86 & & 6.67 & 184 & 331 & 7.14 & & & 108.0 & 18 & 32 & 20 \\
\hline \multicolumn{14}{|c|}{ Group V. ACDI in C bags } \\
\hline 45 & 20 & 92 & & 6.71 & 113 & 296 & 7.97 & & & 23.0 & 5 & 95 & 22 \\
\hline 46 & 21 & 90 & & 6.62 & 131 & 350 & 10.28 & & & & 1 & 96 & 24 \\
\hline $47 \ddagger$ & $\begin{array}{r}0 \\
21\end{array}$ & & $\begin{array}{l}29.5 \\
32.8\end{array}$ & & & & & $\begin{array}{l}163.0 \\
155.0\end{array}$ & $\begin{array}{r}3.6 \\
28.1\end{array}$ & $\begin{array}{r}5.6 \\
32.0\end{array}$ & & 77 & 29 \\
\hline 48 & $\begin{array}{r}0 \\
21 \\
35\end{array}$ & & $\begin{array}{l}31.2 \\
31.9 \\
32.0\end{array}$ & & & & & $\begin{array}{l}166.1 \\
151.0 \\
153.0\end{array}$ & $\begin{array}{r}3.8 \\
31.0 \\
39.0\end{array}$ & $\begin{array}{r}2.1 \\
40.0 \\
67.5\end{array}$ & & $\begin{array}{l}86 \\
58\end{array}$ & $\begin{array}{l}21 \\
28\end{array}$ \\
\hline
\end{tabular}

* Results of two separate bleedings.

$\dagger$ Hemolysis in 0.6 per cent $\mathrm{NaCl}$.

‡ Five hundred $\mathrm{ml}$. transfusion. 
TABLE II-Continued

\begin{tabular}{|c|c|c|c|c|c|c|c|c|c|c|c|c|c|}
\hline Subject & $\underset{\text { storage }}{\text { Days }}$ & MCV & MCHC & $\mathrm{pH}$ & $\begin{array}{c}\text { Lactic } \\
\text { acid }\end{array}$ & Dextrose & ATP & $\mathrm{Na}$ & $\mathbf{K}$ & $\begin{array}{c}\text { Plasma } \\
\text { hb. }\end{array}$ & $\begin{array}{c}\text { Hemolysis } \\
0.63 \% \\
\mathrm{NaCl}\end{array}$ & $\begin{array}{l}24 \mathrm{hr} \text {. } \\
\text { survival }\end{array}$ & $T / 2$ \\
\hline 49 & $\begin{array}{r}0 \\
21 \\
35\end{array}$ & $c u . \mu$ & $\begin{array}{c}\% \\
30.4 \\
31.6 \\
32.3\end{array}$ & & mg. \% & mz. \% & mg. \% & $\begin{array}{c}m E q . / L . \\
156.2 \\
148.2 \\
143.7\end{array}$ & $\begin{array}{c}m E q . / L . \\
3.9 \\
35.3 \\
40.0\end{array}$ & $\begin{array}{r}\text { mg. \% } \\
2.4 \\
38.0 \\
58.0\end{array}$ & $\%$ & $\begin{array}{l}\% \\
88 \\
79\end{array}$ & $\begin{array}{r}\text { day } \\
30 \\
12\end{array}$ \\
\hline 50 & 26 & 90 & & 6.70 & 197 & 279 & 6.57 & & & 118.0 & 8 & 72 & 16 \\
\hline 51 & 27 & 90 & & 6.62 & 195 & 288 & 5.03 & & & 54.0 & 8 & 81 & 30 \\
\hline 52 & $\begin{array}{r}0 \\
28 \\
42\end{array}$ & & $\begin{array}{l}31.4 \\
34.1 \\
32.9\end{array}$ & & & & & $\begin{array}{l}165.1 \\
149.0 \\
135.0\end{array}$ & $\begin{array}{r}3.6 \\
35.5 \\
40.0\end{array}$ & $\begin{array}{r}4.5 \\
55.0 \\
121.1\end{array}$ & & $\begin{array}{l}78 \\
63\end{array}$ & $\begin{array}{l}27 \\
16\end{array}$ \\
\hline 53 & $\begin{array}{r}0 \\
28\end{array}$ & & $\begin{array}{l}29.6 \\
31.5\end{array}$ & & & & & $\begin{array}{l}165.0 \\
127.5\end{array}$ & $\begin{array}{r}4.6 \\
33.6\end{array}$ & $\begin{array}{r}4.5 \\
65.0\end{array}$ & & 85 & 25 \\
\hline 54 & $\begin{array}{r}0 \\
31 \\
42\end{array}$ & & $\begin{array}{l}29.6 \\
31.3 \\
32.3\end{array}$ & & & & & $\begin{array}{l}167.6 \\
132.5 \\
130.0\end{array}$ & $\begin{array}{r}4.3 \\
44.4 \\
45.0\end{array}$ & $\begin{array}{r}4.0 \\
74.5 \\
80.5\end{array}$ & & $\begin{array}{l}73 \\
58\end{array}$ & $\begin{array}{l}17 \\
15\end{array}$ \\
\hline $55 \ddagger$ & $\begin{array}{r}0 \\
35\end{array}$ & & $\begin{array}{l}29.8 \\
31.2\end{array}$ & & & & & $\begin{array}{l}158.0 \\
132.2\end{array}$ & $\begin{array}{r}3.8 \\
40.4\end{array}$ & $\begin{array}{r}4.9 \\
156.0\end{array}$ & & 86 & 22 \\
\hline 56 & $\begin{array}{r}0 \\
35\end{array}$ & & $\begin{array}{l}32.0 \\
32.0\end{array}$ & & & & & $\begin{array}{l}159.0 \\
133.5\end{array}$ & $\begin{array}{r}4.3 \\
36.3\end{array}$ & $\begin{array}{r}9.4 \\
69.5\end{array}$ & & 56 & 26 \\
\hline 57 & 35 & 90 & & 6.62 & 137 & 307 & 6.12 & & & 61.0 & 3 & 67 & 35 \\
\hline 58 & 35 & 87 & & 6.78 & 144 & 282 & 7.99 & & & 51.0 & 9 & 71 & 22 \\
\hline 598 & 36 & & & & & & & & & & & 59 & \\
\hline 608 & 36 & & & & & & & & & & & 64 & \\
\hline $61 \S$ & 36 & & & & & & & & & & & 60 & \\
\hline 62 & 41 & 89 & & 6.58 & 179 & 279 & 6.08 & & & 113.0 & 20 & 44 & 15 \\
\hline 63 & 42 & 91 & & 6.68 & 174 & 315 & 7.16 & & & 113.0 & 17 & 41 & 18 \\
\hline 648 & 42 & & & & & & & & & & & 44 & \\
\hline 658 & 42 & & & & & & & & & & & 49 & \\
\hline 668 & 42 & & & & & & & & & & & 42 & \\
\hline 67 & $\begin{array}{r}0 \\
42\end{array}$ & & $\begin{array}{l}29.8 \\
31.0\end{array}$ & & & & & $\begin{array}{l}162.1 \\
141.0\end{array}$ & $\begin{array}{r}4.1 \\
39.5\end{array}$ & $\begin{array}{r}4.3 \\
68.0\end{array}$ & & 59 & 21 \\
\hline 68 & $\begin{array}{r}0 \\
42\end{array}$ & & $\begin{array}{l}31.1 \\
31.5\end{array}$ & & & & & $\begin{array}{l}157.1 \\
139.1\end{array}$ & $\begin{array}{r}4.2 \\
34.5\end{array}$ & $\begin{array}{r}8.5 \\
118.0\end{array}$ & & 71 & 25 \\
\hline $69 \ddagger$ & $\begin{array}{r}0 \\
42\end{array}$ & & $\begin{array}{l}29.3 \\
30.4\end{array}$ & & & & & $\begin{array}{l}159.0 \\
135.5\end{array}$ & $\begin{array}{r}4.0 \\
41.9\end{array}$ & $\begin{array}{r}4.5 \\
92.0\end{array}$ & & 72 & 22 \\
\hline \multicolumn{14}{|c|}{ Group VI. ACD in $C$ bags } \\
\hline $70 \|$ & 21 & 95 & & 6.71 & 113 & 308 & 8.48 & & & 33.0 & 3 & 85 & 25 \\
\hline 71 & $\begin{array}{r}0 \\
21\end{array}$ & & $\begin{array}{l}32.2 \\
32.6\end{array}$ & & & & & $\begin{array}{l}170.0 \\
152.0\end{array}$ & $\begin{array}{r}4.0 \\
40.0\end{array}$ & $\begin{array}{r}6.6 \\
46.0\end{array}$ & & 99 & 33 \\
\hline 72 & $\begin{array}{r}0 \\
21\end{array}$ & & $\begin{array}{l}32.6 \\
32.7\end{array}$ & & & & & $\begin{array}{l}165.0 \\
155.0\end{array}$ & $\begin{array}{r}4.4 \\
40.0\end{array}$ & $\begin{array}{r}6.4 \\
39.0\end{array}$ & & 73 & 31 \\
\hline
\end{tabular}

\$ Four hundred twenty-five ml. blood.

Average of 10 bloods. 
TABLE II-Continued

\begin{tabular}{|c|c|c|c|c|c|c|c|c|c|c|c|c|c|}
\hline Subject & $\begin{array}{c}\text { Days } \\
\text { storage }\end{array}$ & $\mathbf{M C V}$ & MCHC & $\mathrm{pH}$ & $\begin{array}{l}\text { Lactic } \\
\text { acid }\end{array}$ & Dextrose & ATP & $\mathrm{Na}$ & $\mathbf{K}$ & $\begin{array}{c}\text { Plasma } \\
\text { hb. }\end{array}$ & $\begin{array}{c}\text { Hemolysis } \\
0.63 \% \\
\mathrm{NaCl}\end{array}$ & $\begin{array}{c}24 \mathrm{hr} . \\
\text { survival }\end{array}$ & $\mathrm{T} / \mathbf{2}$ \\
\hline 73 & $\begin{array}{r}0 \\
28\end{array}$ & $c u . \mu$ & $\begin{array}{c}\% \\
28.0 \\
32.7\end{array}$ & & mg. \% & mg. \% & ms. \% & $\begin{array}{c}m E q . / L . \\
176.0 \\
157.5\end{array}$ & $\begin{array}{c}m E q . / L . \\
4.4 \\
16.3\end{array}$ & $\begin{array}{r}\text { mg. \% } \\
6.6 \\
41.0\end{array}$ & $\%$ & $\begin{array}{l}\% \\
68\end{array}$ & $\begin{array}{c}\text { days } \\
26\end{array}$ \\
\hline 74 & $\begin{array}{r}0 \\
28\end{array}$ & & $\begin{array}{l}29.4 \\
29.4\end{array}$ & & & & & $\begin{array}{l}167.0 \\
157.5\end{array}$ & $\begin{array}{r}4.1 \\
13.8\end{array}$ & $\begin{array}{r}5.3 \\
64.0\end{array}$ & & 55 & 26 \\
\hline 75 I & 28 & 96 & & 6.70 & 123 & 288 & 4.89 & & & 52.0 & 3 & 70 & \\
\hline 76 & 35 & 90 & & 6.80 & 128 & 307 & 3.84 & & & 168.0 & 9 & 37 & 15 \\
\hline 77 & 35 & 98 & & 6.70 & 177 & 223 & 3.71 & & & 176.0 & 16 & 54 & 30 \\
\hline 78 & 42 & 93 & & 6.59 & 142 & 284 & 2.67 & & & 126.0 & 7 & 41 & 24 \\
\hline 79 & 43 & 97 & & 6.69 & 170 & 211 & 1.08 & & & 113.0 & 9 & 47 & 20 \\
\hline
\end{tabular}

I Average of 7 bloods.

Lactic acid was determined by the method of Barker and Summerson (6). Adenosine-triphosphate was determined by a method which was an adaption of the procedures described by Fiske and Subbarow (7), Hawk, Oser and Summerson (8), Gomori (9) and Lohmann (10). The remaining in vitro studies were done by standard methods. Before transfusion, Gram-stained smears were examined for bacterial contamination. None was found.

\section{RESULTS}

The results of the studies in vivo and in vitro are summarized in Tables I and II.

Except for an elevated plasma hemoglobin in units collected by vacuum in glass bottles, both initially and on storage, there were no significant differences between the different types of containers. A fall in plasma $\mathrm{Na}$ concentration occurred during storage. Concurrently there was an increase in the plasma $K$. The plasma hemoglobin also increased and an increasing percentage of red cells were hemolyzed in 0.63 per cent $\mathrm{NaCl}$. Variable results were obtained in the measurement of $\mathrm{pH}$, lactic acid and dextrose. However, there was an increase in lactic acid content and a trend toward decreases in both $\mathrm{pH}$ and dextrose on storage. In 35 of 45 determinations the MCHC increased on storage indicating the loss of some water. Inosine did not retard these in vitro changes. However, when adenosine triphosphate (ATP) levels were measured, the blood preserved in inosine showed a higher amount of ATP than control bags not containing inosine (Table II).

In vivo there was little loss of red cells during the first 15 to 30 minutes after transfusion (Figure 1). There appeared to be a greater loss at $30 \mathrm{~min}$ utes of red cells stored in bottles but this was probably not significant. Up to 21 days' storage, there was no apparent difference in vivo between units collected in ACD or ACDI. The survival of the transfused cells at 24 hours is graphically portrayed in Figure 2. All units stored in ACD for 21 days showed at least 70 per cent survival at 24 hours. All units stored in ACDI for periods up to 28 days showed at least 70 per cent survival at 24 hours. However, when storage was continued to from 35 to 42 days the survival of these cells was quite variable. Six of 20 units stored 35 days in ACDI had better than 70 per cent survival at 24 hours. However, only four of 23 units stored 42 or 43 days had 70 per cent survival at 24 hours. Where duplicate studies were performed, the decreased 24 hour survival is readily apparent (Figure 2). The type of container in which the blood was stored did not affect these results.

In general, the viable cells survived well; however, the $T / 2$ decreased as the length of storage increased (Tables I and II). Five of six units stored in ACD had a T/2 of at least 25 days when stored for 28 days. Eight of nine units stored in ACDI for 28 days had a $\mathrm{T} / 2$ of greater than 25 days. However, all 14 units stored 42 days in ACDI had a $T / 2$ of less than 25 days.

In four studies, $450 \mathrm{ml}$. of blood stored in ACDI for 21 to 42 days was transfused. This did not affect the in vivo results (Tables I and II). The 

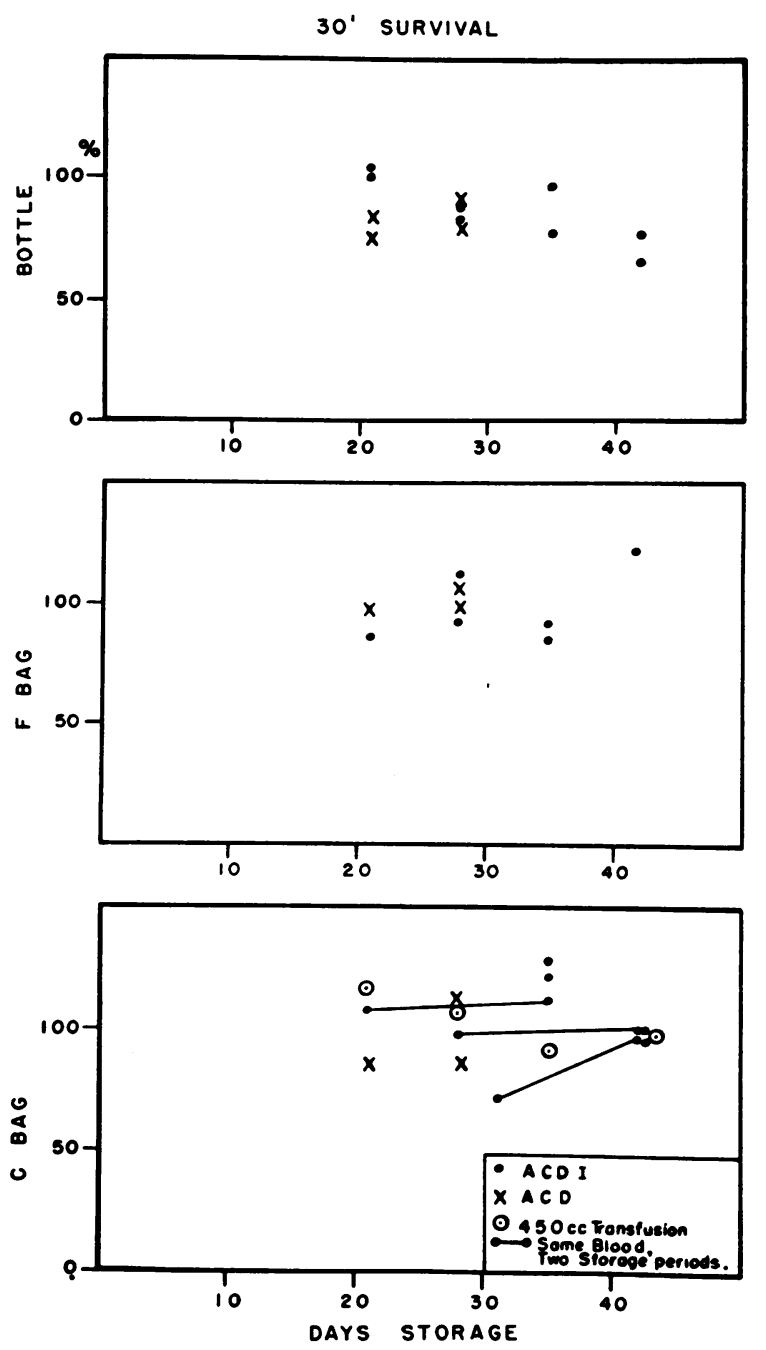

Fig. 1. Comparison of 30 Minute Survival Results in Different Containers, for Varying Periods of Storage Using ACD and ACDI as Preservative Solutions

The percentage is based on the recovery of anticipated counts of radioactivity.

pulse and blood pressure were not affected by the transfusion. In two instances, the uric acid in a 24 hour collection of urine following the transfusion was found to be 1,072 and $1,940 \mathrm{mg}$. (normal values, up to $1,000 \mathrm{mg}$.).

The in vitro survival of red cells stored in two different inosine preparations ${ }^{5}$ sterilized by Seitz filtration was studied. The results are summarized

One preparation obtained from Zellstoff WaldhofWerke, Mannheim, Germany ; one preparation obtained from Schwartz laboratories. in Table III. With few exceptions the inosine employed was unable to effect satisfactory survival at either 36 or 42 days.

It was noted that in some of the specimens of blood stored with the addition of inosine, a rather heavy white precipitate appeared. Samples of this precipitate were tested by Dr. David R. Schwartz and found probably to consist of hypoxanthine. The hypoxanthine content was determined by direct ultraviolet measurement of the precipitate and confirmed by chromatography and spectrophotometric assay of the only ultraviolet absorping spot which appeared on the developed chromatogram.

\section{DISCUSSION}

The action of added inosine in blood preservation has recently been discussed by Gabrio, Donohue, Huennekens and Finch (1) and will not be dealt with in this report.

Gabrio and associates found the average survival of three units of blood studied by both $\mathrm{Cr}^{51}$ and Ashby techniques to be 82 per cent after in vitro storage of five and six weeks in ACDI. While similar results were obtained in 19 per cent of the studies reported here, there were, in general, poor survival results when the storage period was lengthened beyond 28 days. However, inosine did appear able to prolong the storage period for at least seven days.

There were certain technical differences between Gabrio's original study and the studies reported here. In the original study $120 \mathrm{ml}$. of ACD, NIH Formula B, was used. In the present study $67.5 \mathrm{ml}$. of ACD, NIH Formula A, was used. Formula B is composed of : trisodium citrate, $1.32 \mathrm{Gm}$.; citric acid, $0.48 \mathrm{Gm}$.; dextrose, $1.47 \mathrm{Gm}$.; with sufficient water to make $100 \mathrm{ml}$. Formula $\mathrm{A}$ is composed of : trisodium citrate, 2.2 Gm. ; citric acid, $0.8 \mathrm{Gm}$.; dextrose, $2.45 \mathrm{Gm}$.; and sufficient water to make $100 \mathrm{ml}$. Both ACD solutions have been found to give adequate blood preservation for 21 days. With the addition of inosine, however, the effect of the different ACD preservatives used is unknown. In the original study the preservative was sterilized by scintered glass filtration and the inosine was added to the blood within 24 hours after it had been drawn into ACD. In the present study the inosine was added to the ACD and the preservative autoclaved. The 


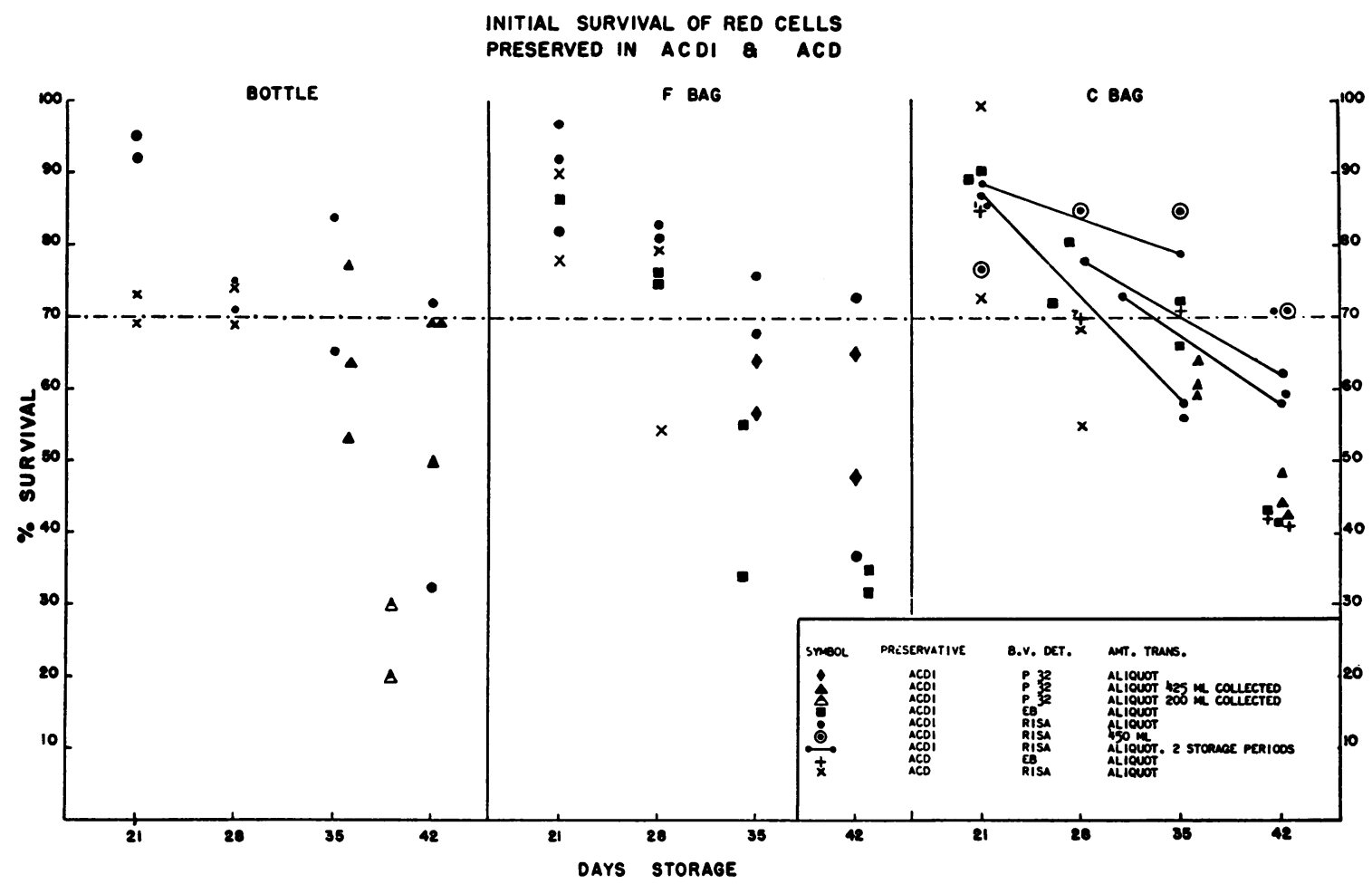

Fig. 2. Comparison of Average 24 Hour Survival Results in Different Containers for Varying Periods of Storage Using ACD and ACDI as Preservative Solutions

manufacturers have stated that inosine can withstand autoclaving. The inosine in both studies was supplied by Schwartz laboratories. Ultraviolet analysis of the inosine used in the present study revealed that the absorption ratios at various wave lengths and the $E$ max were not significantly different from the other inosine preparations made by the manufacturers. The material was submitted to spectrographic analysis and no significant contamination by trace metals was found. The possibility remains, however, that there might be some difference in the inosine preparations. However, as reported in this paper, two different inosine preparations were tested after sterilizing the preservative solution by Seitz filtration. With few exceptions the inosine was unable to effect satisfactory survival at either 36 or 42 days.

Other than the increased number of studies in the present report, the difference in survival results obtained by Gabrio and co-workers (1) remains unexplained. Since some of the samples of blood stored in ACDI in the present study did give satisfactory survival results at 35 and 42 days, it has been suggested that red cells of different individuals may vary in their ability to withstand prolonged storage. Prankerd, in studying the effect of adenosine on the postincubation ability of red cells to utilize glucose, reaccumulate $\mathrm{K}+$ ion and resynthesize phosphate esters after storage, found considerable variability in the response of different blood samples. In fact, many samples failed to revive these metabolic functions at all (11).

The $T / 2$ studies are of interest. The normal range for the $\mathrm{T} / 2$ of unstored blood is 25 to 35 days when $\mathrm{Cr}^{51}$ is used as a tag. For up to 28 days' storage the T/2 of ACDI blood was within normal range. On storage for 35 and 42 days in ACDI, the $\mathrm{T} / 2$ was shortened and this is further evidence of cellular damage on storage.

When the 30 minute survival of transfused red cells was measured, the units collected in glass bottles appeared to show a greater loss of cells than those units collected in plastic packs. This finding is of interest but is probably within the limits of experimental error since the percentage of 
TABLE III

Survival of red cells preserved in various $A C D I$ preparations * $\dagger$

\begin{tabular}{|c|c|c|c|c|c|}
\hline \multirow[b]{2}{*}{ Subject } & \multicolumn{2}{|c|}{ Preservative } & & \multirow{2}{*}{$\underset{\text { storage }}{\text { Days }}$} & \multirow{2}{*}{$\begin{array}{c}24 \mathrm{hr} . \\
\text { survival }\end{array}$} \\
\hline & $\mathrm{ACD}$ & Inosine & of blood & & \\
\hline $\begin{array}{l}80 \\
81 \\
82 \\
83 \\
84 \\
85 \\
86 \\
87 \\
88 \\
89 \\
90 \\
91 \\
92 \\
93 \\
94\end{array}$ & $\begin{array}{l}\text { NIH-A } \\
\text { NIH-A } \\
\text { NIH-A } \\
\text { NIH-A } \\
\text { NIH-A } \\
\text { Modified } \\
\text { Modified } \\
\text { NIH-A } \\
\text { NIH-A } \\
\text { NIH-A } \\
\text { NIH-A } \\
\text { Modified } \\
\text { Modified } \\
\text { NIH-A } \\
\text { NIH-A }\end{array}$ & $\begin{array}{l}\text { S. No. } 105504 \\
\text { S. No. } 105504 \\
\text { S. No. } 105504 \\
\text { S. No. } 105610 \\
\text { S. No. } 105610 \\
\text { S. No. } 105610 \\
\text { S. No. } 105610 \\
\text { S. No. } 105610 \\
\text { S. No. } 105610 \\
\text { G. No. } 14701 \\
\text { G. No. } 14701 \\
\text { G. No. } 14701 \\
\text { G. No. } 14701 \\
\text { G. No. } 14701 \\
\text { G. No. } 14701\end{array}$ & $\begin{array}{rr} & m l . \\
& 425 \\
425 \\
425 \\
\\
200 \\
(0.82 \mathrm{Gm} .) \\
200 \\
200 \\
200 \\
200 \\
200 \\
200 \\
200 \\
200 \\
200 \\
200 \\
200\end{array}$ & $\begin{array}{l}38 \\
42 \\
42 \\
36 \\
36 \\
36 \\
42 \\
42 \\
42 \\
36 \\
36 \\
36 \\
42 \\
42 \\
42\end{array}$ & $\begin{array}{l}\% \\
32 \\
34 \\
34 \\
76 \\
70 \\
70 \\
46 \\
68 \\
61 \\
67 \\
53 \\
55 \\
48 \\
49 \\
55\end{array}$ \\
\hline
\end{tabular}

* One and eight-tenths $\mathrm{Gm}$. of inosine per $450 \mathrm{ml}$. blood.

$\dagger$ Blood stored in bottles; inosine sterilized by Seitz filtration.

¥ Citric acid reduced by half; total citrate unchanged.

viable cells at 24 hours was the same whether collected in bottles or in plastic packs. One observer did find some difference in the survival characteristics of cells stored in two types of packs but this experience was not borne out by the other investigators. One of the investigators also experienced difficulty in the collection of blood in plastic packs without the attached donor set. This difficulty also was not found by the other observers.

Other purine nucleosides have been tested by different techniques for their effect in prolonging the storage period of blood used for transfusion purposes $(12,13)$. Adenosine, one of these nucleosides, prolonged the storage period, but when injected intravenously caused an acute fall in blood pressure (6). This hypotensive effect was not shown by inosine or guanosine which seem able to some extent to improve the storage characteristics of refrigerated red cells $(12,13)$. The purine nucleosides are, however, metabolized to uric acid. While in healthy volunteers the transfusion of $450 \mathrm{ml}$. of blood was without apparent toxicity, the effect of multiple transfusions is not known. The possible toxicity of these purine compounds is under investigation at this time.

These studies have shown that the storage period of refrigerated blood could be extended to 28 days by the addition of $1.8 \mathrm{Gm}$. of inosine to $\mathrm{ACD}, \mathrm{NIH}$ Formula A preservative solution. It is also hoped that the results will stimulate further interest in the effect of inosine on red cell metabolism and preservation.

\section{SUM MARY}

1. Acid-citrate-dextrose (ACD), NIH Formula A solution, with $1.8 \mathrm{Gm}$. of added inosine was studied as a blood preservative.

2. It was compared to ACD solution by in vitro tests and by the survival of $\mathrm{Cr}^{51}$ tagged red cells in vivo.

3. Inosine did not retard the in vitro changes in plasma $\mathrm{Na}, \mathrm{K}$, hemoglobin, lactic acid, dextrose or $\mathrm{pH}$ which occurred on storage. The changes in mean corpuscular hemoglobin concentration (MCHC) and percentage of cells hemolyzed in 0.63 per cent $\mathrm{NaCl}$ were not affected by the addition of inosine to the preservative solution. However, blood stored in inosine did show an increased amount of adenosine triphosphate when compared to blood preserved in ACD alone.

4. Using the criteria of 70 per cent survival of red cells 24 hours post-transfusion, blood may be stored in ACD for 21 days. In ACD to which inosine has been added (ACDI), blood may be stored for 28 days.

5. Slightly elevated urinary uric acid levels were found in two subjects after the transfusion of 450 ml. of blood. The possible toxic effects of multiple transfusions are not known. 


\section{ACKNOWLEDGMENT}

The authors gratefully acknowledge the technical assistance of Ann Berman, Barbara Burrows, Louise Colwell, Mario Escobar, Mary E. Hickey, Ingeborg Hedrick and Nancy Stone.

\section{REFERENCES}

1. Gabrio, B. W., Donohue, D. M., Huennekens, F. M., and Finch, C. A. Erythrocyte preservation. VII. Acid-citrate-dextrose-inosine (ACDI) as a preservative for blood during storage at $4^{\circ} \mathrm{C}$. J. clin. Invest. 1956, 35, 657.

2. Strumia, M. M., Colwell, L. S., and Dugan, A. The measure of erythropoiesis in anemias. I. The mixing time and immediate post-transfusion disappearance of $\mathrm{T}-1824$ dye and of $\mathrm{Cr}^{\text {s1 }}$-tagged erythrocytes in relation to blood volume determination. Blood 1958, 13, 128.

3. Gibson, J. G., II, and Scheitlin, W. A. A method employing radioactive chromium for assaying the viability of human erythrocytes returned to the circulation after refrigerated storage. J. Lab. clin. Med. 1955, 46, 679.

4. Donohue, D. M., Motulsky, A. G., Giblett, E. R., Perzio-Biroli, G., Viranuvotti, V., and Finch, C. A. The use of chromium as a red cell tag. Brit. J. Haemat. 1955, 1, 249.

5. Lange, R. D., Escobar, M. R., and Crosby, W. H.
In vitro and in vivo studies of acid-citrate-dextroseinosine (ACDI) as a blood preservative. Walter Reed Army Institute of Research Report 24-57.

6. Barker, S. B., and Summerson, W. H. Colorimetric determination of lactic acid in biological material. J. biol. Chem. 1941, 138, 535.

7. Fiske, C. H., and Subbarow, Y. Colorimetric determination of phosphorus. J. biol. Chem. 1925, 66, 375.

8. Hawk, P. B., Oser, B. L., and Summerson, W. H. Practical Physiological Chemistry, 12th ed. Philadelphia, Blakiston, 1947.

9. Gomori, G. Modification of colorimetric phosphorus determination for use with photoelectric colorimeter. J. Lab. clin. Med. 1941-42, 27, 955.

10. Lohmann, $K$. Uber die Isolierung verschiedener natürlicher Phosphorsäure-verbindungen und die Frage ihrer Einheitlichkeit. Biochem. Z. 1928, 194, 306.

11. Prankerd, T. A. J. Chemical changes in stored blood, with observations on the effects of adenosine. Biochem. J. 1956, 64, 209.

12. Donohue, D. M., Finch, C. A., and Gabrio, B. W. Erythrocyte preservation. VI. The storage of blood with purine nucleosides. J. clin. Invest. 1956, $35,562$.

13. Prankerd, T. A. J. Revival of stored blood with guanosine and its successful transfusion. Lancet 1956, 1, 469. 